\title{
Blended Training Development on Technical Competency Training for Family Planning \\ Instructors (PKB) with Junior Expert Position in National Population and Family Planning Board
}

\author{
Cucu Nurpalah 1
}

cucunurpalah@upi.edu

\begin{abstract}
This study aims to analyze the duties of the junior expert family planning instructors (junior expert PKB), analyze the existing technical training curriculum for the junior expert $P K B$, design the blended training curriculum for technical training for the junior expert $P K B$, and evaluate the blended training curriculum for technical training for the junior expert PKB. The method used in this research was design and development, developed by Richey and Klein with three stages: analysis, design and development, and evaluation. In general, the competency standards formulated for the junior expert PKB focus on assessment and evaluation of IEC (information, education, and communication), advocacy, recording and reporting to data and information analysis. Meanwhile, the strategy used in training was blended learning by combining face-to-face learning and e-learning. The evaluation was carried out using portfolio assessment. This training curriculum design was assessed by curriculum and e-learning experts in the form of expert reviews with very good results and suitable for use. Moreover, based on the feasibility test conducted on the user, the blended training curriculum developed was very good and suitable for use in technical competency training for the junior expert PKB.
\end{abstract}

Keywords: Blended Learning, Training Curriculum, Technical Competence

Abstrak: $\quad$ Penelitian ini bertujuan untuk menganalisis tugas PKB ahli pertama, menganalisis kurikulum pelatihan teknis PKB ahli pertama yang sudah ada, mendesain blended training curriculum untuk pelatihan teknis bagi PKB ahli pertama, dan mengevaluasi blended training curriculum untuk pelatihan Teknis bagi PKB Ahli Pertama. Metode yang digunakan dalam penelitian ini adalah design and development yang dikembangkan oleh Richey and Klein dengan tiga tahapan yaitu analysis, design and development dan evaluation. Secara umum standar kompetensi yang dirumuskan bagi PKB ahli pertama berfokus pada penilaian dan evaluasi KIE, Advokasi, Pencatatan dan Pelaporan hingga Analisis Data dan Informasi. Sedangkan startegi yang digunakan dalam pelatihan adalah blended learning dengan memadukan pembelajaran tatap muka dan e-learning. Evaluasi yang dilakukan menggunakan peniliaian portofolio. Desain kurikulum pelatihan ini diberikan penilaian oleh para ahli kurikulum dan e-learning berupa expert review dengan hasil sangat baik dan layak untuk digunakan. Dan berdasarkan uji kelayakan yang dilakukan kepada user bahwa kurikulum blended training yang dikembangkan sangat baik dan layak untuk digunakan dalam Pelatihan Kompetensi Teknis Bagi PKB Ahli Pertama.

Kata Kunci: $\quad$ Blended Learning, Kurikulum Pelatihan, Kompetensi Teknis

Submitted: September $2020 \quad$ Reviewed: December $2020 \quad$ Accepted: March $2021 \quad$ Published: March 2021


he existence of Human Resources (HR) in an organization is a valuable asset. The success of an organization is determined by the quality of the people in it. HR will work optimally if the organization can support its employees' career advancement by looking at what competencies exist or must be possessed. Competency-based HR development will support employee performance so that work quality is better and leads to optimal performance achievement. Employee capability is a crucial element in improving employee performance in an agency (Nusaku, 2014).

Competency-based HR development is carried out to provide results according to the organization's goals and objectives with predetermined performance standards, namely professional HR. In this case, the professionalism of the State Civil Apparatus (ASN) is achieved if he can carry out public services well (Komara, 2019). To become a professional, ASN has the right to get increased competence, both technical, managerial, and socio-cultural competencies. Efforts to increase ASN's capacity are carried out through education and training, which impact their professionalism as civil servants (Komara, 2019). Therefore, education and training implementation must be carried out professionally with continuous guidance as regulated in laws and government regulations. As the education and training provider, the National Population and Family Planning Education and Training Center is responsible for improving ASN's quality in the National Population and Family Planning Board (BKKBN). The training carried out must be based on the employees' needs and development plans (Kamil, 2013).

Data from the BKKBN Field Line Development Directorate contained 14,920 PKBs (Family Planning Instructors) who participated in competency certification in 2017. The results revealed that $29 \%$ PKBs were categorized as above standard, 2\% PKBs were classified according to standards, and $69 \%$ PKBs were classed as requiring further development. Based on the certification results, it was found that technical competence was the competence domain that most required follow-up development. It is clear evidence of the need for training. Besides, in 2018, the BKKBN recruited quite a number of new employees to form the junior expert PKB; of course, training is also needed to carry out their duties properly.

The need for increasing technical competence in PKB is also supported by research conducted by Suhenda (2018) regarding the consumer satisfaction index (IKK) for PKB performance in West Java Province that overall, the value of the consumer satisfaction index on PKB performance in West Java Province in 2018 amounted to 71.89 with the service quality category $C$, meaning that the performance was not good. When viewed from the service element, the service time had the smallest index value of 0.29 with an average service element value of 2.64. Of the ten PKB work steps, there were only two considered good, namely the approach to formal figures and monev RR, while the other eight work steps were not going well, including data collection and mapping, the informal figure approaching, village level meetings, affirmation of agreements, exemplary, IEC (information, education, and communication), and family planning guidance.

Regarding training needs, based on the BKKBN strategic plan (renstra) for 2020-2024, the target percentage of competent personnel is civil servants in the BKKBN who participate in classical and/or non-classical training, who meet the established passing limits and receive the results of the satisfaction index assessment. Minimum satisfactory education and training must reach $80 \%$ by 2024 of the 2018 ASN BKKBN baseline of 17,470 people. Based on the strategic plan, the Population and Family Planning Education and Training Center (KKB) must train as many as 14,678 ASN BKKBN over the next five years. Most of these are family planning instructors (PKB). PKBs who take part in the training are PKBs who have taken the competency tests, and the results of their competency tests 
require follow-up development. For this reason, training is carried out as a follow-up to improve PKB competencies to meet competency standards.

However, one of the obstacles faced by PKB in the field is the lack of innovation in information delivery, which affects the acceptance of information understanding. In this case, what is meant is information, education, and communication (IEC), which is one of the PKB's duties to explain to the public about the KKBPK (Population Family Planning and Family Development) program (Setyowati et al., 2016). It is in line with research on the correlation of messages with the participants' attitudes in the national family planning counseling program at the auxiliary health centers, showing the results that the IEC process was still ineffective. It is based on the practical implications in the research that it is expected that PKB must be able to work according to its duties and functions as a PKB must have good insight and ability to communicate with the community. PKB must be able to become a communicator who plays a role in delivering messages/information effectively so that people can become good communicators. Besides that, PKB must be able to carry out its role optimally so that the family planning program implementation can run well (Maulida, MR et al., 2017). This statement is strengthened in research on the BKKBNs' role in population management through the family planning program. According to the study, the BKKBN program's failure was partly due to the family planning socialization process, which still faced many obstacles, one of which was the minimal role of PKB in carrying out its duties (Rahman, 2019).

A preliminary study was conducted through documentation and interviews. Based on the documentation study in the 2018 Family Planning Instructor profile book, 69\% (10,274 people) were categorized as needing follow-up development. From these results, it was known that the technical competencies needed improvement the most, including 1) collecting IMP (Rural Community Institutions) data; 2) carrying out training for IMP cadres; 3) development of advocacy media, IEC, counseling; 4) initiating and facilitating the formation of BKB (Toddler Family Development), BKR (Youth Family Development), BKL (Elderly Family Development), PIK-R/M (Information and Counseling CenterYouth/University Student), and UPPKS (Efforts to Increase Prosperous Family Income) groups; 5) monitoring and evaluating KKBPK programs.

From the results of interviews and documentation studies with the Personnel Bureau and the Directorate of Field Line Development, it was found that there have been updates related to Guideline 2 of 2017 regarding competency standards, especially for the junior expert PKBs. From the initial requirement of having 19 technical competencies, it was changed to five technical competencies: 1) formulation of population control policies, family planning, and family development; 2) advocating for population control, family planning, and family development policies; 3) KKBPK recording and reporting; 4) analysis of KKBK data and information; 5) IEC KKBPK. To see the extent to which the understanding related to these five competency standards was carried out, a self-assessment was conducted on the junior expert PKBs. The results obtained were that the junior expert PKBs assessed themselves as applying the demographic concepts in carrying out their duties and functions. For IEC competencies, on average, the participants felt that they had applied the concepts related to IEC competencies. For concepts related to advocacy competence, on average, the participants rated themselves as having applied the concept. For concepts related to recording and reporting competencies, including recording, reporting, potential data cards, data recapitulation, and Family Information Systems (SIGA), the junior expert PKBs assessed that they had implemented the concept.

Related to the above, there is a need to improve competencies, especially PKB technical competencies, one of which can be done through training. Ganesh (2015) stated that training benefits employees and the company if carefully planned and implemented appropriately. Training is a systematic process for changing employee behavior to achieve organizational goals. The purpose of training is to increase new skills, knowledge, or expertise (Patrick, 1992). This training has a major 
impact on employee performance compared to coaching, empowerment, and participation (Suharnomo, 2013). The training provided is a type of substantive technical training that aims to provide substantive knowledge and skills to achieve civil servant competence, in this case, PKBs, to professionally carry out their duties and responsibilities (LAN, 2011). Training has a positive impact on improving performance but is relatively moderate on improving government officials' performance (Syaifar, 2015).

Based on education and training achievement data taken from the Education Information System (SIDIKA) in 2019, 3,287 PKBs participated in technical competency improvement training. This number represented $24.3 \%$ of the total number of PKBs in Indonesia. The above conditions illustrate that the Population and Family Planning Education and Training Center must have a good strategy to be able to fulfill employee competency development rights, especially PKBs. The training strategy referred to is the development of effective methods in increasing competence and efficient methods of reaching training participants.

In responding to employee development needs, especially junior expert PKB, education and training institutions must be able to provide student-oriented learning and have an integrated system to facilitate access to the learning implementation. Ease of access and availability of learning resources that suit individuals' needs are forms of the agile learning institution (Basseng, 2020). The ability to combine learning with technology is very much needed, considering that many things positively impact the organization. The training implementation becomes more efficient and effective, both through elearning and blended learning. It corroborates with what was stated by Suwardi (2017) that web-based e-learning, when combined with conventional training, could increase the trainees' competence effectively.

Blended learning also offers good benefits for organizations, including as stated by Pandey (2017) that blended learning (1) enables organizations to reach a broader audience in a much shorter time; (2) shorter sitting time; (3) online framework allows instructors to assess the participants' performance online and much more quickly; (4) microlearning or gamification provided by blended learning gives an immersive learning experience aimed at better memory, retention, and application; (5) the blended training approach is learner-centered and gives students better control over adjusting the pace at which they want to learn; (6) offers much better collaboration, including online discussions, messages, feedback, and a platform for communicating with peers and instructors. Of course, all these advantages are aimed at achieving training objectives, namely increased competence.

For ASN, blended learning provides an opportunity to take control of the success of the training independently. The trainee can decide when to start, when to finish, and which part of the module he wants to study first. If, after repeating, there are still things not understood, participants can contact the lecturer/instructor/resource persons via e-mail/chat or participate in interactive dialogues at specific times. It is one of blended learning's advantages, namely flexibility. Another advantage is that participants do not have to be in the training building; they can carry out other job responsibilities, which, of course, make it difficult to attend face-to-face classes (Poon, 2013).

To achieve targeted training in accordance with the training objectives in increasing the junior expert PKBs' competence, a reference is needed, namely the curriculum as the basis for implementing the training. Of course, the developed curriculum is based on the technical competency standards of the junior expert PKBs. PKB competency standards refer to Guideline Number 2 of 2017 concerning PKB competency standards, in which PKB is required to have 19 technical competencies. However, the competency standards in the regulation have not divided competencies according to the level of position, so that the standard changes have been made according to the PKB position level. 
Nurhajati's research (2014) asserts that competency enhancement training for family planning instructors is a competency-based curriculum. Training is held with the aim that there are no discrepancies in the competencies expected of training participants. The competency-based education and training curriculum (KBK) is a curriculum concept that emphasizes the development and mastery of specific competencies. The low PKB competence can be improved through education and training, one of which is through e-learning-based training to increase PKB's learning independence, which in turn can improve learning outcomes and competence (Nurhajati, 2018). Competency-based competency development is also one of the activities in line with the BKKBN strategic plan policy for 2020-2024.

Furthermore, competency-based blended training is a competency-based training curriculum that utilizes information and communication technology developments to provide training, which is expected to be effective and efficient in achieving standard competencies as a junior expert PKB. Based on the description above, this research focuses on analyzing the duties of the junior expert PKB, analyzing the existing junior expert PKB technical training curriculum, designing the blended training curriculum for technical training for the junior expert $\mathrm{PKB}$, and evaluating the blended training curriculum design for technical training for the junior expert PKB.

\section{RESEARCH METHODS}

This study used the design and development method from Richey and Klein (2007). Design and development are one of the studies on conducting design, development, and evaluation processes by testing a theory and validating it by establishing procedures, techniques, or steps to create a product that can be used for development. This method was chosen because this study aimed to create a training curriculum product, namely blended training, to improve technical competence for the junior expert PKB.

This study's subjects were lecturers and stakeholders of the Population and Family Planning Education and Training Center and lecturers from the BKKBN Representative Office for West Java, Banten, Central Java, and East Java Provinces.

The sample determination employed purposive sampling, in which the sampling technique was with specific considerations. The research targets were ten people from the Population Education and Training Center and the Central National Population and Family Planning Board (BKKBN KB) West Java; Training, Research, and Development of West Java BKKBN Representatives; Training, Research, and Development of Central Java BKKBN Representatives; Training, Research, and Development of East Java BKKBN Representatives.

The number of stakeholders interviewed was five people, consisting of administrators of the Population and Family Planning Education and Training Center, supervisory officers of the Personnel Bureau, and administrative officers from the Directorate of Field Line Development. The research stages were as follows. 1) Analysis was the initial stage carried out to identify needs. In this study, the needs analysis of the activities carried out based on the junior expert PKB's duties, curriculum analysis with lecturers, and interviews related to training policies with stakeholders. 2) Design and development were the stages of making a design or blueprint, and then real product development was carried out. At the design and development stage, the activities carried out were identifying competencies, linking competencies with the curriculum, assessing competencies, making designs, and developing elearning. 3) Evaluation was the data analysis stage based on the previous stage. At this stage, the activities carried out were expert assessments or reviews by curriculum experts, e-learning experts, and due diligence. Data analysis on the assessment of curriculum design experts used a Likert scale: very bad, bad, good enough, good, and very good. 
Meanwhile, for e-learning experts, the criteria used were unsuitable, sufficiently suitable, suitable, and very suitable. The criteria also had a range of scores for categorization. The data were then analyzed utilizing descriptive statistics. According to Ali (2014), descriptive statistical analysis is a statistic used to analyze data by describing the collected data as they are without intending to make generalized conclusions or generalizations.

\section{RESULTS AND DISCUSSION}

\section{Job Analysis for Junior Expert PKB Position}

The competencies needed to be able to carry out the duties of junior expert PKB are first to be equipped with knowledge and skills about planning, organizing, conceptual thinking, analysis, information seeking, and cooperation. According to Kaufman (1972), job analysis is an analytical activity to record and describe a function or position's task in system analysis to identify performance units. It concurs with the task-needs analysis by Wireman (2013), which examines what tasks an individual must perform, what activities must be completed to perform those tasks, and what knowledge and skills are required to perform each task. In analyzing tasks, Kaufman (1972) affirmed that two basic steps could be taken, including (1) identifying the main tasks (or steps) involved in achieving the overall function and (2) determining the characteristics of the task, requirements, context, and put chronologically.

According to Jonassen, Tesmen and Hannum (2009), the instructional designer performs a job analysis to determine (1) learning goals and objectives; (2) the operational components of the job, skills, or learning objectives to describe what the task forces do, how they perform tasks or apply skills, and how they think before, during, and after learning; (3) what knowledge is expressed (declarative, structural, and procedural knowledge), which characterizes the job or task; (4) which tasks, skills, or objectives should be taught, namely how to select appropriate learning outcomes for learning development; (5) which tasks are most important, which have priority for training resource commitments; (6) the order in which tasks are performed and must be learned and taught; (7) how to select or design teaching activities, strategies, and techniques to encourage learning; (8) how to select suitable media and learning environments; (9) how to build performance appraisals and evaluations.

\section{Analysis of the Technical Training Curriculum for the Junior Expert PKB}

Based on the interview results, it could be concluded that the formulation of objectives should be clear, measurable, and achievable. This formulation should contain the mastery of attitudes, skills, and behaviors in accordance with the standards of the family planning instructors regarding the substance of the Population Family Planning and Family Development Program. The classical training strategy was considered quite effective; however, some argued that if the training were carried out with blended learning, it would be more efficient in using the budget. Another opinion stated that classical methods in the class were not yet effective because they could be developed with other methods, such as on job training or simulations. The learning resources used were modules, broadcast materials prepared by Widyaiswara, SKATA applications, reference books available in libraries, case books, journals and even YouTube. For learning media, it was considered maximal and effective in supporting learning, be it learning facilities in the classroom, field, and ICT tools.

The formulation of objectives to be developed in the curriculum requires further adjustments considering differences between the formulation of competency indicators in the standard competency document and the rules for writing ideal curriculum objectives. According to Doll (in Ornstein \& Hunskin, 2009), "objectives should address the intellectual (or cognitive), the social-personal (or affective), and the productive." Objectives, or in the competency-based curriculum called competency standards, must 
contain the values of knowledge, attitudes, and skills, which lead to job competency standards, particularly the junior expert PKB.

Although the classical training strategy was considered quite effective, some argued that if the training were conducted with blended learning, it would be more efficient in using the budget. According to Allan (2007), blended learning programs can include (1) good integration between face-to-face and/or e-learning; (2) use various media, including text, audio, or video podcasts; (3) provide alternative approaches to learning, for example reading material choices, media, and face-to-face and online activities; (4) give alternative approaches to assessment, e.g., written assignments, group assignments, multiple-choice tests; (5) provide alternative approaches to contacting and working with tutors, including face-to-face sessions, e-mail and messaging systems, telephone, and online discussion groups.

Moreover, Pandey (2017) stated that blended learning (1) enables organizations to reach a broader audience in a much shorter time; (2) shorter sitting time; (3) online framework allows instructors to assess the participants' performance online and much more quickly; (4) microlearning or gamification provided by blended learning gives an immersive learning experience aimed at better memory, retention, and application; (5) the blended training approach is learner-centered and gives students better control over adjusting the pace at which they want to learn; (6) offers much better collaboration, including online discussions, messages, feedback, and a platform for communicating with peers and instructors.

In general, Susilana and Riyana (2009) described learning media functions: "(1) clarifying the message so that it is not too verbal; (2) overcoming the limitations of space, time, energy, and senses, (3) generating passion for learning, more direct interaction between students and learning resources, (4) enabling students to learn independently according to their visual, auditory, and kinesthetic talents and abilities; (5) giving the same stimulation, equalizing experiences, and causing the same perception."

The evaluation carried out in the previous training used test assessment techniques through a pretest and posttest to measure learning achievement. According to Sanders (in Ornstein \& Hunskin, 2009), evaluation is a formal determination of the quality, effectiveness, or value of a program, product, project, process, goal, or curriculum. The evaluation includes investigation and assessment methods: (1) determining standards for assessing quality and deciding whether they should be relative or absolute; (2) gathering relevant information; (3) applying standards to determine quality. Assessment techniques should also use a combination of tests and non-tests to measure all competency types in the training participants. Besides, the evaluation used should also show the training participants' progress as a whole. In this case, according to Kim (2015), the portfolio seems to have the potential to integrate these methods and is an effective appraisal for formative and summative performance.

\section{Design and Development}

Competency-based curriculum development in this study adopted competency-based curriculum development carried out by Kim (2015) with the following steps: 


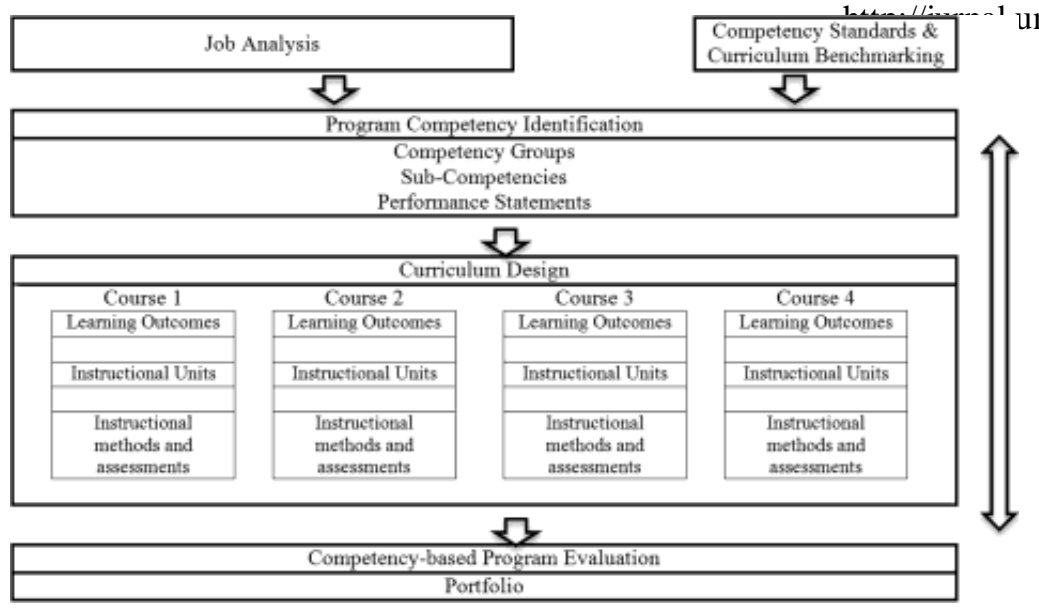

Figure 1. Competency-Based Curriculum Theory Framework (Joenghyun Kim, 2015)

\section{The Formulation of Competency Standards}

The first step in implementing the design is to formulate competency standards. The formulated competency standards are that "after participating in this training, participants are expected to be able to assess and evaluate policies, IEC, advocacy, recording and reporting to data analysis carried out in extension, services, mobilization, and development of KKBPK programs". From the formulation of the basic competencies and indicators above, if connected with the junior expert PKB's duties and functions as contained in the Permenpan RB (Regulation of the Ministry of State Apparatus Empowerment and Bureaucratic Reform) Number 21 of 2018, it can be seen which competencies support the junior expert PKB's tasks. The explanation is as follows.

When viewed from the basic competencies and indicators of evaluating the text and implementing population control, family planning, and family development policies, the junior expert PKB's duties are (a) compiling the KKBPK program planning through development planning deliberations at the village level; (b) arranging KKBPK coordination meetings at the district/city level; (c) evaluating the KKBPK program at the district/city level; (d) preparing weekly, monthly, and annual work plans for the KKBPK program in the target area; (e) monitoring and evaluating the KKBPK program at the sub-district level. Meanwhile, seen from the formulation of success indicators, the operational verbs used are analyze, do, make/do, and evaluate. When viewed from the level of the learning domain, the verbs are at the C3 (analysis), C4 (application), and C5 (evaluation) levels.

When viewed from the basic competencies and indicators of preparing instruments, materials, strategies, and implementation of KKBPK policy advocacy, the junior expert PKB's tasks are (a) preparing KKBPKB facilitation services at the sub-district level; (b) facilitating KKBPK services at the sub-district level; (c) advocating for formal and informal figures at the sub-district level; (d) facilitating partnerships with formal and informal organizations at the sub-district level; (e) facilitating partnerships with formal and informal organizations at the sub-district level.

In the competency standards and indicators of designing the format, procedures, and standards for recording and reporting and using the SIGA application, the junior expert PKB's tasks are (a) designing a data collection instrument; (b) testing the data collection instrument; (c) processing the family data collection results at the district/city level; (d) creating a map of the IMP (Rural Community Institutions) data collection at the district/city level.

Besides, the junior expert PKB's duties regarding basic competencies and indicators of interpreting data into good quality information are (a) conducting data collection results at the sub- 
district level; (b) compiling coordination meeting materials at the district/city level; (c) evaluating the KKBPK program at the district/city level; and (d) monitoring and evaluating the KKBPK program at the sub-district level.

Concerning the basic competencies and indicators of conducting IEC and the ability to measure the effectiveness of its implementation, the junior expert PKB's duties are (a) designing KKBPK exhibition activities at the sub-district level; (b) organizing mass media IEC; (c) assessing the KKBPK program competition at the sub-district level; (d) carrying out coaching of the BKB, BKR, BKL, UPPKS, PIK-R potentials and other social activities at the district/city level; (e) preparing and implementing the KKBPK program service facilitation at the sub-district level; (f) developing information technology-based IEC media at the district/city level; (g) presenting the results of the information technology-based IEC media development. From the formulation of these indicators, it can be seen that the operational verbs used are understand, determine, do, and make.

\section{Formulation of Competence into Material}

Meanwhile, the formulation of competencies into the material can be seen in the material structure below:

Table 1. Curriculum Material Structure

\begin{tabular}{|c|c|c|c|c|c|}
\hline \multirow[b]{2}{*}{ No. } & \multirow[b]{2}{*}{ Competence } & \multirow[b]{2}{*}{ Material } & \multicolumn{2}{|c|}{ Strategy } & \multirow[b]{2}{*}{ Total } \\
\hline & & & $\begin{array}{c}\mathrm{E}- \\
\text { Learning }\end{array}$ & $\begin{array}{l}\text { Face to } \\
\text { face }\end{array}$ & \\
\hline & $\bar{A}$ & Core Materials & & & \\
\hline 1. & $\begin{array}{l}\text { Formulation of policies on } \\
\text { control of the population, family } \\
\text { planning, and family } \\
\text { development }\end{array}$ & $\begin{array}{l}\text { Assessing and evaluating } \\
\text { the implementation of } \\
\text { population, family planning, } \\
\text { and family development }\end{array}$ & 3 & 5 & 8 \\
\hline 2. & $\begin{array}{l}\text { Advocating control policies for } \\
\text { population, family planning and } \\
\text { family development }\end{array}$ & $\begin{array}{l}\text { Advocating for the } \\
\text { implementation of } \\
\text { population, family planning, } \\
\text { and family development } \\
\text { policies }\end{array}$ & 4 & 6 & 10 \\
\hline 3. & Recording and reporting & $\begin{array}{l}\text { Family information system } \\
\text { (SIGA) }\end{array}$ & 3 & 7 & 10 \\
\hline 4. & $\begin{array}{l}\text { Data and information analysis } \\
\text { of population, family planning, } \\
\text { and family development }\end{array}$ & $\begin{array}{l}\text { Analyzing data and } \\
\text { information on population, } \\
\text { family planning, and family } \\
\text { development }\end{array}$ & 4 & 5 & 9 \\
\hline 5. & $\begin{array}{l}\text { IEC KKBPK (information, } \\
\text { education, and communication } \\
\text { of population, family planning, } \\
\text { and family development) }\end{array}$ & $\begin{array}{l}\text { The effectiveness of } \\
\text { information, education, and } \\
\text { communication of } \\
\text { population, family planning, } \\
\text { and family development }\end{array}$ & 2 & 6 & 8 \\
\hline & $\mathrm{B}$ & Supporting Materials & & & \\
\hline 1. & & $\begin{array}{l}\text { Program briefing and } \\
\text { explanation of blended } \\
\text { learning }\end{array}$ & 2 & - & 2 \\
\hline 2. & & Follow up plan & 2 & 2 & 4 \\
\hline & & Total & 18 & 41 & 49 \\
\hline
\end{tabular}


In linking competencies to the curriculum, what must be done is to adjust the performance statement, both the basic competency standards and the indicators, with each training's learning outcomes. In the formulation of objectives, it appears that the formulation has described the specific competencies that must be taught, and this specific matter relates to the junior expert PKB's duties. It is in accordance with what was said by Mc Neil (2006) that the formulation of training objectives is to determine the specific competencies that must be taught so that training participants can carry out their duties and achieve targets.

These materials allow participants to learn knowledge, skills, and attitudes about how to do the five things above. It is a practice of using the principle of relevance put forward by Sukmadinata (in Wahyudin, 2014), where the curriculum content must be relevant to the society's demands, needs, and development. In this case, the material taught is in line with the job analysis of the junior expert PKB. According to Ornstein and Hunskin (2009), in this way, the content learned will enable participants to use the knowledge in work situations and other activities.

\section{Training Strategy}

The strategy used was a blended learning approach, combining face-to-face learning and elearning. In this e-learning session, participants took part in activities starting from the program's opening and briefing through the Zoom meeting webinar, filled in attendance, and took the pretest. After that, the participants were given the freedom of time to access the material presented. The training participants could access the next material if they sent the assignment given. Learning activities were provided in the form of developed e-learning, consisting of synchronous program opening and directing activities. Training participants could read the material provided in the scorm package format, which was also available in PowerPoint format, watch learning videos, and do the assignments given. As reinforcement, a live chat feature was also provided, facilitating interaction between participants and other participants and the facilitator synchronously.

Face-to-face learning sessions at the Population and Family Planning Education and Training Center had 31 lesson hours or five effective days. The activities carried out face-to-face are learning activities to analyze KKBPK program activities' strategy, make KKBPK program planning at the subdistrict level on the worksheets provided, fill in the KKBPK program monitoring and evaluation worksheets, fill in the worksheets for determining strategic advocacy issues, practice network mapping using netMap, practice SMART advocacy (simulations and case studies), make advocacy follow-up plans, discuss advocacy follow-up plans, practice recording and reporting through the SIGA application (family information system), practice data analysis methods and techniques, work on data interpretation case studies, make instruments to work on case studies of analysis and conclusions in data and information analysis, make IEC (information, education, and communication) implementation measurement instruments, practice IEC in communities that have been conditioned by training providers, evaluate the IEC's effectiveness, and make a follow-up IEC plan in the form of project-based assignments.

In this face-to-face session, it was clear that the learning activities carried out were more practical and direct practice, not much material delivery, which had been done in the previous elearning sessions.

In this study, it appears that two strategies were carried out: face-to-face activities and elearning. More precisely, the concept of combining the two activities is blended training. The concept of blended training is actually blended learning; it is called blended training because, in this case, it is used in the context of training. The combination of two activities, face-to-face and e-learning, is in line with Allan (2007) that blended learning is a combination of face-to-face and e-learning. Semler (in Husamah, 2014) stated that blended learning combines the best aspects of e-learning and face-to-face learning. Williams, Bland, and Christie (in Poon, 2013) defined blended learning as a combination of 
traditional face-to-face learning and distributed learning, allowing lecturers, students, and content to be in different locations. In more detail, according to Sharpe (in Allan, 2007), the learning aspects that can be combined are time (both synchronous and asynchronous), place (on-campus, work, or at home), different technologies, pedagogical aspects, and learner's focus and type.

\section{Evaluation of Competency Achievement Assessment}

In measuring the five competencies, it was carried out using tests and non-tests. The types of tests used were multiple-choice questions and the performance test. Meanwhile, the non-test type used case studies. According to iStudy Penn State University (2017), a case-based assessment instrument evaluates the extent to which students can handle authentic, real-world problems.

At the end of the session, participants were given project-based assignments. Participants were allowed to design activities. These activities were carried out and reported in a report, and the report assessment was performed. These assignment results were collected for portfolio assessment. Portfolios could serve as a good competency assessment method by making students responsible for providing evidence of their learning outcomes and the process, how they have developed, and where further learning is needed (McMullan in Kim, 2015).

\section{Design and Development Evaluation}

Design and development evaluation was carried out by expert evaluation or expert reviews. In this study, the assessments were done by curriculum experts, e-learning experts, and users, namely the BKKBN Population and Family Planning Education and Training Center, which has the authority in terms of PKB training.

\section{Curriculum Expert Assessment}

Curriculum expert assessment focused on assessing aspects of objectives, materials, strategies, and evaluation. In the objective component, the assessment indicators are the suitability of training objectives with organizational needs, coherence between objectives, competencies, and indicators of learning outcomes, the formulation of training objectives, the formulation of training competencies, and the formulation of learning outcome indicators. It is essential to assess because curriculum developers have an obligation to show the relationship between the objectives formulated in training (basic competencies and indicators) with bigger goals (competency standards) (Zais, 1976).

In the material component that becomes the assessment indicator, according to Ornstein and Hunskin (2009), the suitability of the material with the training objectives, the sequence of the material, the scope of the material, the depth of the material, and the usefulness of the material are often assessed in terms of how the content being studied, which will enable students to use that knowledge in work situations and other adult activities. It is crucial to assess because the evaluation aspects and forms must be precise and measure the training's objectives and success.

Table 2. Curriculum Design Expert Assessment

\begin{tabular}{cccccc}
\hline No & Aspects & $\begin{array}{c}\text { Number of } \\
\text { Grains }\end{array}$ & Ideal Score & $\begin{array}{c}\text { Score } \\
\text { Acquisition }\end{array}$ & Percentage \\
\hline 1 & Objectives & 10 & 50 & 45 & 90 \\
\hline 2 & Material & 10 & 50 & 4 & 90 \\
\hline 3 & Implementation strategy & 8 & 40 & 36 & 90 \\
\hline 4 & Evaluation & 6 & 30 & 27 & 90 \\
\hline
\end{tabular}

Based on the assessment given by curriculum design experts, it could be concluded that the blended training curriculum design for technical competency training for the junior expert PKB made was very good and suitable for use. 
In the e-learning expert assessment instrument, the assessment components are the interface design, the availability of teaching materials, the availability of learning activities, and the availability of assessment tools. These five things are the components adopted from the theory put forward by Hadjerouit (in Zyainuri, 2013) that the three main factors that must be present in e-learning are pedagogy, content, and technology aspects. The pedagogical aspects that must be present are the learning design, teaching methods, assessment methods, and learning strategies. The media expert assessment results of the blended training curriculum design are as follows.

Table 3. E-Learning Expert Assessment

\begin{tabular}{cccccc}
\hline No & Aspects & $\begin{array}{c}\text { Number of } \\
\text { Grains }\end{array}$ & $\begin{array}{c}\text { Ideal } \\
\text { Score }\end{array}$ & $\begin{array}{c}\text { Score } \\
\text { Acquisition }\end{array}$ & Percentage \\
\hline 1 & Interface Design & 5 & 20 & 19 & 95 \\
\hline 2 & Availability of Teaching Materials & 4 & 16 & 16 & 100 \\
\hline 3 & Availability of Learning Activities & 4 & 16 & 14 & 87.5 \\
\hline 4 & Availability of Assessment Tools & 4 & 16 & 16 & 100 \\
\hline
\end{tabular}

Comments given overall from e-learning experts were that Moodle-based e-learning in the development of blended training for technical competency training for the junior expert PKB was very good and suitable for learning and research purposes.

\section{Feasibility Test}

This feasibility test assessment aimed to assess curriculum and e-learning products designed from the user's point of view, namely the BKKBN Population and Family Planning Education and Training Center, which has the authority in terms of PKB training. The assessment results are as follows.

Table 4. Feasibility Test Results

\begin{tabular}{cccccc}
\hline No & Aspects & $\begin{array}{c}\text { Number of } \\
\text { Grains }\end{array}$ & $\begin{array}{c}\text { Ideal } \\
\text { Score }\end{array}$ & $\begin{array}{c}\text { Score } \\
\text { Acquisition }\end{array}$ & Percentage \\
\hline 1 & Objectives & 10 & 50 & 48 & 96 \\
\hline 2 & Material & 10 & 50 & 44 & 88 \\
\hline 3 & Implementation Strategy & 12 & 60 & 53 & 88.3 \\
\hline 4 & Evaluation & 6 & 50 & 23 & 76.67 \\
\hline
\end{tabular}

Overall, the blended training curriculum developed was very good and suitable for use in technical competency training for the junior expert PKB. In principle, the use of live chat was to provide good interaction between participants and other participants and between participants and the facilitator. It is a form of social presence and teaching presence put forward by Garison and Akyol (2013), which must be present in e-learning. Live chat as a form of reinforcement was also a forum for interaction that should exist, facilitating training participants to express opinions/thoughts and assess themselves in the middle of their social learning environment. Further, the live chat facility is the right forum to rectify any irregularities or misperceptions on material given.

\section{CONCLUSION AND SUGGESTION}

Based on the job analysis results, the junior expert PKB technical competencies that currently required development were five technical competencies: policy formulation, advocacy, IEC, recording and reporting, and data and information analysis. The curriculum made by the Central BKKKBN 
Population and Family Planning Education and Training Center has met the curriculum preparation needs and rules in general. However, related to the existence of a new policy on the competency standards of the junior expert PKB, the Population and Family Education Training Center has not yet made a technical curriculum, so a junior expert PKB technical training curriculum is needed, which refers to the latest competency standards adjusted to the position level.

Blended training curriculum design for technical competency training for the junior expert PKB is a competency-based curriculum designed to meet these needs. The formulated competency standards are that the junior expert PKB can assess and evaluate policies, IEC, advocacy, recording and reporting to data and information analysis. This blended training curriculum and e-learning products developed were assessed through expert curriculum design tests, e-learning media expert tests, and due diligence by users. The results of the curriculum design expert test obtained an assessment that the designed curriculum was very good and suitable for use in training. Besides, from the expert test results, the developed e-learning media was very good and suitable for use. According to user assessments, the developed blended training and e-learning curriculum were very good and suitable for use.

\section{REFERENCES}

Allan, Barbara. (2007). Blended Learning Tools For Teaching and Training.London: Facet Publishing

Ali, M. (2014). Memahami Riset Perilaku dan Sosial. Jakarta: Bumi Aksara.

Ali, M.(2017). Curriculumm Development for Sustainability Education. Bandung : Upi Press.

Badan Kependudukan dan Keluarga Berencana Nasional. (2017). Materi Profil Penyuluh KB/Penyuluh Lapangan KB Tahun 2017. Jakarta: BKKBN.

Badan Kependudukan Keluarga Berencana Nasional. (2018). Survei Kinerja dan Akuntabilitas Program KKBPK (SKAP) Keluarga Tahun 2018. Jakarta; BKKBN.

Basseng. (2020). Tantangan dan Strategi Lembaga Pelatihan Membangun ASN Unggul. Jakarta: Lembaga Administrasi Negara.

Ganesh, M. (2015). Importance and Effectiveness of Training and Development. Mediterranean Journal of Social Sciences, 6 (1).

Garrison and Akyol. (2013). The Community of Inquiry Theoretical Framework: In the Context of Online and Blended Learning. Diakses dari: https://www.researchgate.net/publication/284306348 The Community of Inquiry Theoretical Fr amework

Husamah. (2014). Pembelajaran Bauran (Blended Learning). Jakarta: Prestasi Pustaka

Jonassen, Martin Tessmer, Wallace H. Hannum. (2009). Task Analysis Methods Forlnstructional Design. New York: Routledge

Kamil, Mustofa. (2013). Model-Model Pelatihan. Diakses dari: http://file.upi.edu/Direktori/SPS/PRODI.PENDIDIKAN_LUAR_SEKOLAH/196111091987031-

MUSTOFA_KAMIL/Bhaan_kuliah/Model-model_pelatihan.pdf

Kaufman, Roger A. (1972). Educational System Planning.USA: Prentice Hall

Kementerian Pendayagunaan Aparatur Sipil Negara dan RB.(2018) Permenpan RB Nomor 21 tahun 2018 tentang Jabatan Fungsional Penyuluh Keluarga Berencana. Jakarta: Menpan RB

Kim, Jeonghyun. (2015). Competency Based Curriculum: An Effective Approach to Digital Curation Education. University Of North Texas. Diakses dari: https://files.eric.ed.gov/fulltext/EJ1082900.pdf 
Komara, Endang. (2019). Kompetensi Profesional Pegawai ASN (Aparatur Sipil Negara) di Indonesia. MIMBAR PENDIDIKAN: Jurnal Indonesia untuk Kajian Pendidikan, Volume 4(1), Maret, pp.73-84. Bandung, Indonesia: UPI [Indonesia University of Education] Press, ISSN 2527-3868 (print) and 2503-457X (online).

Lembaga Administrasi Negara. (2011). Peraturan Kepala Lembaga Administrasi Negara Nomor 13 Tahun 2011 Tentang Pedoman Umum Pembinaan Penyelenggaraan Pendidikan dan Pelatihan Teknis. Diakses dari: http://ppid.lan.go.id/wp-content/uploads/2014/10/Perkalan-no.13-Tahun2011-Tentang-Pedoman-Penyelenggaraan-Diklat-Teknis.pdf

Maulida, MR., Sukarelawati \&AA Kususmadinata. (2017). Korelasi Pesan Dengan Sikap Peserta Penyuluhan Program Keluarga Berencana nAsional Di Puskesmas Pembantu. Jurnal Komunikatio Volume 3 Nomor 2, Oktober 2017.

McNeill, John D.(2006). Contemporary Curriculum In Thought And Acion.USA: John Wiley\& Sons, Inc.

Meyer \& Booker. (2001). Eliciting and Analizing Expert Judgment. London: American Statistical Association and The Society for industrial and Applied Mathematics.

Nusaku, Legendaria.(2014). Analisis Pegaruh Kemampuan Dan Kompetensi Terhadap Kinerja Pegawai. Jurnal Sains Manajemen Volume III, Nomor 1, April 2014. Diakses dari: http://www.jsmmsmupr.com/wp-content/uploads/2015/06/10-LEGENDARIA.pdf

Nurhajati, W. A. \& Bachri, B. S.(2014). Pengembangan Kurikulum Pendidikan dan Pelatihan (Diklat) Berbasis Kompetensi Dalam Membangun Profesionalisme Pegawai Negeri Sipil (PNS).

Nurhajati, W. A. (2018). Peningkatan Kompetensi Penyuluh Keluarga Berencana Provinsi Jawa Timur Melalui Diklat Berbasis E-learning. Proceedings of the ICECRS, 1(3), 183-196. https://doi.org/10.21070/picecrs.v1i3.1395

Ornstein, Allan C \& Hunskin, Francis. (2009). $5^{\text {Th }}$ Edition Curriculum Foundations, Principles and Issues. USA: Pearson.

Pandey, Asha.(2017). 5 Reason Why You Should Adopt Blended Training. Diakses dari: https://elearningindustry.com/blended-training-reasons-adopt

Patrick, J. (1992). "Training: Research and Practice". London: Academic Press Inc.

Penn State University. (2017). Alternative Assessment. Diakses dari: http://tutorials. istudy.psu.edu/testing/testing7.html.

Poon, Joanna. (2013). Blended Learning: An Institutional Approach For Enhancing Students' Learning Experiences. Diakses dari: https://jolt.merlot.org/vol9no2/poon 0613.pdf

Rahman, M.Ali. (2019). Peran BKKBN Dalam Mengatur Kependudukan Indoesia Melalui Program Keluarga Berencana. Diakses dari: https://www.researchgate.net/publication/336698824_PERAN_BKKBN_DALAM_MENGATUR_KE PENDUDUKAN_INDONESIA_MELALUI_PROGRAM_KELUARGA_BERENCANA

Richey and Klein. (2007). Design and development research. New York : Routledge

Riduwan. (2013). Rumus dan Data Dalam Analisis Statistika. Bandung: Alfabeta.

Setyowati, Evi., Arsiyah \& Ahmad Riyadh. (2016). Peran Petugas Lapangan Keluarga Berencana dan Pembantu Pembina Keluarga Berencana Desa Dalam Mensosialisasikan Alat Kontrasepsi. JKMP (ISSN.2338-445X dan E-ISSN.2527 9246), Vol.4, No.2, Sepetember 2016, 117-234.

Suhenda, Dadang. dkk. (2019). Indeks Kepuasan Konsumen Terhadap Kinerja PKB di Provinsi Jawa Barat. Latbang Perwakilan BKKBN Provinsi Jawa Barat 
Syaifar, Bujang. (2015). The effectiveness of education and training management of the pubic servants at the Center of Education and Training of Ministry of Domestic Affairs Regional Bukittinggi. Diakses dari: https://eric.ed.gov/?id=EJ1075868

Sugiyono. (2014). Memahami Penelitian Kualitatif. Bandung: Alfabeta.

Susilana dan Riyana. (2009). Media Pembelajaran: Hakikat, Pengembangan, Pemanfaatan dan Penilaian. Bandung: CV.Wacana Prima.

Wahyudin, Dinn.(2014). Manajemen Kurikulum. Bandung: PT Remaja Rosdakarya

Zais, Robert.s.(1976). Curriculum Principles and Foundations. New York: Harper \& Row Publishers.

Zyainuri \& Marpanji. (2013). Penerapan E-learning Moodle untuk Pembelajaran Siswa Yang Melaksanakan Prakerin. Diakses dari: https://www.researchgate.net/publication/328454080_Penerapan_elearning_moodle_untuk_pembelajran_siswa_yang_melaksanakan_prakerin

Wireman, Terry. (2013). Training Programs for Maintenance Organizations. USA: Terrence O'Hanlon. 